\title{
A tale of three cities: Aesthetico-cultural cosmopolitanism as a new capital among youth in Paris, Sao Paulo, and Seoul \\ DOI:
}

10.1177/1469540518818629

\section{Document Version}

Accepted author manuscript

Link to publication record in Manchester Research Explorer

Citation for published version (APA):

Cicchelli, V., Octobre, S., Riegel, V., Katz-Gerro, T., \& Handy, F. (2021). A tale of three cities: Aesthetico-cultural cosmopolitanism as a new capital among youth in Paris, Sao Paulo, and Seoul. Journal of Consumer Culture, 21(3), 576-597. https://doi.org/10.1177/1469540518818629

\section{Published in:}

Journal of Consumer Culture

\section{Citing this paper}

Please note that where the full-text provided on Manchester Research Explorer is the Author Accepted Manuscript or Proof version this may differ from the final Published version. If citing, it is advised that you check and use the publisher's definitive version.

\section{General rights}

Copyright and moral rights for the publications made accessible in the Research Explorer are retained by the authors and/or other copyright owners and it is a condition of accessing publications that users recognise and abide by the legal requirements associated with these rights.

\section{Takedown policy}

If you believe that this document breaches copyright please refer to the University of Manchester's Takedown Procedures [http://man.ac.uk/04Y6Bo] or contact uml.scholarlycommunications@manchester.ac.uk providing relevant details, so we can investigate your claim.

\section{OPEN ACCESS}




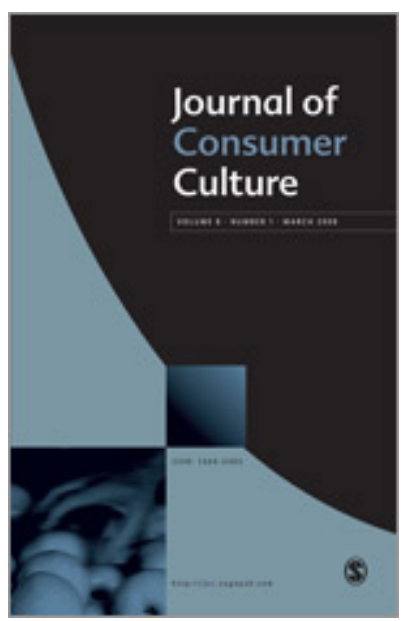

\section{A Tale of Three Cities: Aesthetico-cultural cosmopolitanism as a new capital among youth in Paris, São Paulo and Seoul}

\begin{tabular}{|c|l|}
\hline Journal: & Journal of Consumer Culture \\
\hline Manuscript ID & JOCC-18-0081.R1 \\
\hline Kanuscript Type: & Original Article \\
\hline Keywords: & $\begin{array}{l}\text { aesthetic-cultural cosmopolitanism, youth, cross-national comparison, } \\
\text { cultural consumption, globalization of culture }\end{array}$ \\
& $\begin{array}{l}\text { This paper adds to the literature on the consequences of cultural capital } \\
\text { at the age of cultural globalization by analyzing the ways youth engage } \\
\text { in globalized cultural consumption in three cities - Paris, São Paulo and } \\
\text { Seoul. Drawing on cosmopolitanism as an aesthetic and cultural stance } \\
\text { of openness and on global cultural consumption as providing youth with } \\
\text { cosmopolitan skills, we compare the uses of aesthetico-cultural } \\
\text { cosmopolitanism in three contexts. We offer an original account of } \\
\text { different uses of cosmopolitan cultural skills, which, to varying degrees in } \\
\text { the three contexts, signal generational belonging, social distinction, } \\
\text { educational and professional success and personal eruditeness and } \\
\text { fulfillment. Analysis of recent interviews with 80 youth in each city } \\
\text { reveals distinct uses of aesthetico-cultural cosmopolitanism: as a vehicle } \\
\text { for self-development (either empowerment or Bildung) in Paris; as a } \\
\text { means for the cultivation of social capital for personal status in São } \\
\text { Paulo; and as human capital serving for labor market entry and } \\
\text { attainment in Seoul. Our findings accentuate that even with the } \\
\text { prevalence of cultural globalization in global cities, the functions of } \\
\text { cosmopolitan skills remain highly dependent on educational, institutional, } \\
\text { cultural, and political contexts at the national level, which create } \\
\text { different incentives and opportunities or barriers to experiencing } \\
\text { otherness and developing new types of cultural capital. }\end{array}$ \\
\hline
\end{tabular}




\section{SCHOLARONE ${ }^{m}$ Manuscripts}




\section{A Tale of Three Cities: \\ Aesthetico-cultural cosmopolitanism as a new capital among youth in Paris, São Paulo and Seoul}

\section{Introduction}

One of the main focal points for research in the sociology of culture has been cultural capital, i.e. the relationships between the skills brought on by cultural consumption patterns and structures of power and inequality in society (Bourdieu, 1984), in terms of employability (Tomlinson, 1999), educational attainment (Sullivan, 2001), and social networks (Lizardo, 2006; Warde and Tampubolon, 2002). Such research has rarely adopted a country-comparative point of view as a tool to extend the theory of cultural stratification and has not specifically focused on the effects of the globalization of culture on the formation of cultural capital.

To address these two gaps, we add to the literature an analysis of the strategic uses of global cultural consumption by youth in cities located in the West (Paris), the South (São Paulo) and the East (Seoul). We discuss the emergence of a new cultural capital in large urban settings that take a leading role in the globalization process, as major sites for the interplay between migration, cultural interpretation and processes of inequality (Sassen, 2001).

We draw on cosmopolitanism as "a cultural disposition involving an intellectual and aesthetic stance of 'openness' towards peoples, places and experiences from different cultures, especially those from different "nations"' (Szerszinski and Urry, 2002: 468), and focus on a specific type of cosmopolitanism that centers around aesthetic and cultural codes associated with the consumption of globalized cultural products. Cosmopolitanism is particularly relevant in those urban settings (Yeoh, 2005), where the search for the exotic is the norm (Johnston and Baumann, 2014). A key dimension of the globalization that takes place in cities is the making of a new social class of educated individuals who are engaged in cultural consumption and who follow new aesthetic, cultural, ethical and political norms and values associated with a cosmopolitan orientation.

We show how young individuals, in Paris, São Paulo and Seoul manifest curiosity and interest for products and practices whose aesthetic and cultural codes are situated outside of their own national aesthetic canon and cultural corpus. We further show how they employ this aesthetico-cultural cosmopolitanism in three distinctive ways: as a vehicle for self-development (either empowerment or Bildung) in Paris, as a 


\section{Conceptualizing aesthetico-cultural cosmopolitanism}

The globalization of cultural industries has initiated significant social and cultural changes, requiring an account of new post-nationally defined cultural skills and dispositions. The proliferation of information coming from every part of the world produces a complex lexicon of aesthetic and cultural possibilities, with a densely connected network of global icons and imaginaries (Appadurai, 1996) that have been analyzed through the perspective of cosmopolitanism (Papastergiadis, 2012). The globalization of cultural industries has also accelerated the aestheticization of everyday life (Molz, 2011), which increasingly defines people by their cultural consumption, signaling generational belonging, social distinction, educational and professional success and personal eruditeness and fulfillment.

Existing research approaches globalized cultural consumption with diverse emphases, but all studies see the consumption of foreign cultural products as indicators of openness toward the culture of the 'other.' Whether value-laden (Meuleman and Savage, 2013) or inadvertent (Cappeliez and Johnston, 2013; Lamont and Askartova, 2002; Regev, 2013), the consumption of culturally diverse products has been dubbed "global cultural consumption." The cosmopolitan perspective provides an appraisal of the mechanism of individual openness to the culture of the 'other' (Beck, 2006; Kendall et al., 2009; Skrbis and Woodward, 2013), linking aesthetic and cultural interests with a moral concern about a common belonging to humanity.

Cicchelli and Octobre (2018) offer a definition of aesthetico-cultural cosmopolitanism as a specific orientation toward otherness, i.e., as an individual engagement with cultural images, global cultural icons, and cultural products that originate in "other" ethno-national cultures, forging imaginaries and emotions and providing opportunities to learn new aesthetic and cultural codes. Aesthetico-cultural cosmopolitan skills enable individuals to traverse physical and cultural borders (Mau et al., 2008), to situate their own cultures in a historical perspective with respect to other cultures (Szerszynski and Urry, 2006), to be engaged in international social relationships (Molz, 2011; Hannerz, 1990), to be culturally ambidextrous (Dharwadker, 2011) and to be able to transcend the global-local opposition and live in a 'glocal cultural universe' (Szerszynski and Urry, 2002: 471 ; Robertson, 1992).

Analysis of globalized cultural consumption reveals a relationship between aesthetico-cultural cosmopolitanism and structures of inequality and social stratification (Coulangeon, 2017; Rössel and Schroedter, 2015). For example, urban youth and students tend to be more cosmopolitan than rural youth 
and workers (Cicchelli and Octobre, 2017; Katz-Gerro, 2017). Youth tend to be more cosmopolitan because they are placed in the midst of dynamic cultural flows, are highly skilled in multicultural interactions and develop a cultural awareness, openness and knowledge (Seo and Gao, 2015). In the educational context, which legitimizes cosmopolitanism as a desirable disposition, academic qualifications that signal cosmopolitanism are increasingly profitable to individuals in jobs requiring interactions with people of multiple nationalities (Igarashi and Saito, 2014).

Building on this literature, this paper presents an original attempt to document and analyze aestheticocultural cosmopolitanism as a new form of cultural capital that can influence social inequality, either by favoring those with such a capital in the labor market or in a social status market. To do this, we examine how young individuals in three global cities use aesthetico-cultural cosmopolitanism and how different contexts condition the uses of cosmopolitan cultural capital.

\section{Youth in the three global cities}

The comparative design of this research allows us to problematize the notion of the 'other' (often the ethno-national other) which stands at the center of the cosmopolitan perspective (Beck and Grande, 2010), and to avoid an ethnocentric appraisal of alterity. Because empirical research on cultural cosmopolitanism has often focused on Western societies, it often entailed perceiving the Eastern and the Southern as the other (Pieterse, 2006). Since the end of the Cold War and the rise of new players in the global arena, a symmetrical approach of the 'other' is warranted; as perceived from the West (France), the South (Brazil), or the East (Korea).

Cities are major sites for the flourishing of cosmopolitan skills that can be unequally distributed and that tightly link cultural consumption, power and class to potentially constitute a new cultural capital (Savage et al., 2018: 142). Our chosen sites - Paris (and its suburbs), São Paulo, and Seoul - comparable in size of population, are global cities that can nurture the emergence of a cosmopolitan orientation. The place of the three cities in the global arena can be compared on two dimensions: 1) position in the flow of global cultural products, and 2) diversity of population. Information on both dimensions is summarized in Appendix Matrix 1. Paris has a long-lasting worldwide influence and is an established global player (Lombard, 2003); São Paulo is trying to build a regional influence and is an aspirant in the global cultural arena (Ablas, 1993); meanwhile, Seoul rises as a new cultural power (Jin, 2016). In terms of population diversity, there is a high proportion of mixed origins in Paris and São Paulo, whereas Seoul's population is homogeneous. 
Each city shapes a different globalized youth, as summarized in Appendix Matrix 2. In Paris, youth (1829 ) represent approximately $17 \%$ of the population as compared to $36 \%$ elsewhere in France, and the level of unemployment among youth is lower (18.4\%) than in the rest of the country (24.9\%). This population has mixed origins: $52 \%$ of youth born in Paris had foreign origins associated with mixed marriages between locals and immigrants (Tribalat, 2013). The level of education has been rising (80\% or more reaching baccalaureate and $60 \%$ going to university), but there is also an increasing distrust of the educational system in its ability to prepare youth for the job market (Maurin, 2009). The level of English proficiency of young French people remains low (EF English proficiency Index, 2018), and the educational system remains defensive toward the introduction of courses in English at the university level (Héran, 2013). Yet, Paris also benefits from strong foreign multilateral cultural flows: the influence of American culture is strong but not exclusive, and influences from Europe, Asia, and Latin America are also important. However, ethnic minorities and immigrant communities, residing in Paris, do not see their cultural heritage or languages legitimized in the curriculum of the public-school system. ${ }^{1}$

In São Paulo, ${ }^{2}$ youth (18-29) represent only $9.2 \%$ of the population as compared to being $14.3 \%$ nationally. Few of them have a university education, but São Paulo has one of the highest rates of educated youth in the country (4.3\% versus 1.5\%). Nevertheless, youth in São Paulo face a high level of unemployment (24.1\% versus the higher national average of 27.8\%) (IBGE, 2014). A low proportion of the population in São Paulo is foreign-born (2.3\%) and even lower among the 18-29 age bracket (1.8\%) However, a large percentage of the population self-declares to be mixed-race (43.1\%), including indigenous and African. São Paulo is an important center of cultural production and activities with a concentration of companies and cultural intermediaries supported by private companies and the local government. Existing fiscal incentives to the private sector help create greater accessibility to and visibility of international cultural products. Although there is a high consumption of mainstream global cultural products, there exists a distinct demand for local ones. The primary origin of cultural flows comes from United States for films, TV series, music, and video games.

In Seoul, youth (15-24) make up nearly 13\% of the population of 10.4 million. Higher education is taken very seriously among Koreans as educational status is a source of family pride and remains a prerequisite for enhancing one's socioeconomic position in society. Not surprisingly, nearly all of the youth graduate

\footnotetext{
${ }^{1}$ The last attempt to introduce optional lessons in Arabic in the primary school system led to a very tense social debate and was rapidly abandoned.

${ }^{2}$ IBGE, 2010. www.ibge.gov.br/censo2010
} 
from high school (99\%), and over 68\% in the general population have post-secondary degrees (Moon, 2015). One of the purposes of gaining a higher education and developing proficiency in English is to obtain soughtafter jobs in Korean conglomerates as well as high-paying jobs in transnational companies (Koo, 2007). Few immigrants are attracted to South Korea because of its language and strict immigration policies. And, although policies are becoming more pro-immigration due to low birth rates, foreign residents make up only $2.8 \%$ of the total population (Moon, 2015).

In summary, processes of modernization, immigration, and globalization provide the backdrop for analysis of the way that traditional hierarchies are evaded by aesthetico-cultural cosmopolitanism in the three cities under consideration.

\section{Methodology and data collection}

To explore the uses of aesthetico-cultural cosmopolitanism among youth in our three global cities, we adopted an approach based on personalized narratives of interviewees about their global cultural consumption. We designed an open-ended interview instrument, which was initially tested, validated, and used in France. We used trained social scientists in Sao Paolo and Seoul to translate and back translate the interview protocol, going through several iterations to make sure the questions are adapted to the local cultural context.

The interview protocol aimed at identifying patterns of global cultural consumption, the vocabularies of motives associated with these patterns (Grauel, 2016) and the consequences of aesthetico-cultural cosmopolitanism in everyday life. The interviews covered five main themes: a) Preference for cultural products (movies, television series and programs, video games, comic books / graphic novels, magazines, books, and media consumption) and criteria for appreciation (e.g., preferences regarding ethno-national origin or for language). b) Narratives about the foreign countries depicted in/by the cultural products and imaginaries about these countries stemming from their cultural products. c) Interest in a foreign country or region of the world and/or self-definition as a cosmopolitan. d) Cultural capital and cultural resources (e.g., language skills, geographic mobility). e) Socio-demographic data concerning the interviewee and their family.

In Paris, a snowball method was used, starting from students and leading to their contacts. Although the resulting sample is not representative, it does depict a variety of social contexts, including students and workers from different backgrounds, with a good gender balance. Eighty in-depth interviews were conducted between 2013-2015 with youth aged 18-29 years old, 53\% female, from various social (25\% lower class, 


\section{The uses of aesthetico-cultural cosmopolitanism: Toward a new capital?}

\subsection{Paris: self-improvement or Bildung}

In Paris, a taste for a variety of foreign cultural products coexists with a strong preference for consuming their "original version," i.e., relying on subtitles rather than dubbed versions or scans in the case of manga. This preference exists even when language proficiency is low, demonstrating how taste is embedded within an aesthetic respect and an appreciation for real sounds and an authentic ambiance. Curiosity draws young individuals to cultures that are regarded as more exotic than familiar, for example, mangas or Korean pop music, regardless of any existing diaspora or language proficiency. Cosmopolitan skills are strongly aestheticized, aesthetics being the first way to encounter otherness, in a context of a multicultural urban area. The most common configuration of aesthetico-cultural cosmopolitanism is linked to cultural selfimprovement, either empowerment or Bildung, in a context of intense multicultural flows providing easy access to foreign and/or national cultural contents. 
The first, empowerment, takes place for youth who possess fewer social and cultural resources. For them, aesthetico-cultural cosmopolitanism is associated with a strong desire to transcend one's social and cultural horizons as well as one's social location. Aesthetico-cultural cosmopolitanism is a resource used for individual emancipation from social constraints. Camille (20), a waitress, provides a typical example. She holds a baccalaureate in Economics and Social Sciences and lives in a housing project where she shares an apartment with her working-class parents. The closed-off world of the lower-class suburbs to the north of Paris where she lives nevertheless offers unexpected resources, and Camille's cultural consumption choices help her to mark her distance vis-à-vis her community of origin and its value. By using aesthetico-cultural resources as a launching pad, Camille gains access to different cultures and redefines herself as a cosmopolitan person; she says:

I think that I don't have any power over the countries that surround me but on the other hand, I can try to understand, I can try to find out more about those cultures.

By describing herself as "an individual in the world," Camille tries to transform her aesthetico-cultural cosmopolitanism into a resource, hoping to travel abroad and to raise her children in a cosmopolitan fashion by giving them a taste for travel and foreign languages:

I haven't travelled a lot but I intend to make up for it when I have the money, I want to travel at least once a year, I want my children to travel so that they can see that there's more than just France and our customs, and if I have the means I want to put them in a bilingual school because I want them to be fluent at least in English, and why not other languages, I think that in the years to come Chinese is going to become somewhat necessary. To go back to me - so I want to travel, I'm interested in what's around me and not just in France, honestly I feel like if I really put my mind to it I could master English really well, Spanish too, so yeah at any rate I think I can say that I'm cosmopolitan.

The second use of aesthetico-cultural cosmopolitanism identified among the Parisian youth is of an enlightened self-education, i.e., Bildung. Contrary to empowerment, this type occurs in a context of abundant resources. For example, Frédéric (22), pursuing a master's degree in political science in a major Parisian university, consumes a large number of cultural products from a wide variety of foreign countries. Frédéric has inherited the cosmopolitan legacy of mobile cultural elites - his mother is French, his stepfather is German, both executives; Frederic lived in Germany, travelled a lot both for study and leisure and speaks French, German, and English. Frederic demonstrates fluency moving between different aesthetic and 


\title{
5.2 São Paulo: social inclusion
}

The interviews in São Paulo show that cultural products, both national and international, are highly valued by the elite who seek the social status to be involved with artists and producers and to be perceived as part of a cultural scene. Lower status social groups do not have the same access to resources often due to language barriers. Although São Paulo is home to immigrants from Japan, China, and South Korea, cultural products from these countries are still considered exotic and not likely to be appreciated or consumed. The consumption of American products, mainly in English, is very important, especially for individuals in the middle and upper social strata of society.

The uses of cosmopolitan skills are mainly associated with individuals' socioeconomic background. First, individuals of the upper classes with abundant resources use their aesthetico-cultural cosmopolitan skills to enhance their social capital. Marina (20), a undergraduate student whose mother and father are business executives, explains:

\begin{abstract}
Since I was very young I used to travel with my parents, and the experience of knowing other countries became an important ingredient in my life. (...) I think the fact that I want to know more about the world creates in me a natural interest for international music, films, series, like it is a way of connecting to other reality out of my country, without necessarily traveling. (...) The fact that I know people in other countries also helps me with references, like a band nobody knows here in São Paulo, or a TV show they watch only in the United States.
\end{abstract}

These opportunities made it possible to consume international cultural goods, mainly from North America and in English. Like Marina, youth from the upper classes have had a strong cultural influence either from their family or from their educational background, and through these means they develop their 
cosmopolitan capital (Weenink, 2008) with the feeling of belonging to the world. Furthermore, in São Paulo, the link between cultural consumption and cultural proximity is also strong, as Lucas (23), male administrative assistant (whose mother is a public employee and father is deceased) affirms:

I have friends who are from Japanese families and I tried to read mangas a few times, but I think they are very difficult to understand, or even to enjoy it.

The second use of cosmopolitan skills in São Paulo relates to individuals with scarce resources, who are part of the lower class and face barriers in accessing foreign languages and international travel experiences. However, they are also interested in other cultures. Their exposure relies on the consumption of mainstream products and vicariously through the lives of media celebrities. The findings illustrate the possibility of hybridization, a way of connecting the local to foreign elements that have especially an aesthetic appeal. For example, even though youth wish to consume foreign products, they often consume domestic products due to language barriers. However, they do watch international films or TV programs that are dubbed. Ricardo (18), a male retail store employee whose mother is unemployed and father is a construction worker explains:

I only listen to music or watch TV in Portuguese, because I don't speak English, I don't even speak Portuguese very well (...). I always watch films dubbed in Portuguese too. (...) I choose films that have famous actors, they usually are the ones I like the most.

Hybridization is another way by which youth in São Paulo connect famous foreign symbols, familiar because of their visibility on mainstream media, to local products that are connected to the local context. For example, an aesthetic adaptation in the translation of foreign codes that are unrelated to local codes, as Isadora (22), a female undergraduate student and receptionist in a doctor's office, whose mother is a cook in a restaurant and father is unknown to her, points out:

I think that many musicians and groups in Brazil try to copy the American style. Their songs and their video clips are very similar to the last Beyoncé hit, it's like mandatory, if you want to have success, follow them. (...) Also I think it is good that these Brazilian groups create a version of a American song or videoclip, so we can understand it, as well as we feel it is more integrated to our home, like showing some of our own things, like our city, neighborhood.

\subsection{Seoul: educational and occupational attainment}


The data from Seoul point to acquisition of aesthetico-cultural cosmopolitan skills by youth being instrumental for educational and occupational attainment. This is reasonable in a country that is poor in natural resources and therefore highly dependent on its human capital resources. Young individuals strive for educational attainment as a way to be successful and find it profitable to transform cosmopolitan aesthetico-cultural consumption into human capital. There is recognition that gaining cosmopolitan capital is very much part of the current generation's educational asset as Chae-won (22), a female working in a lunch take-away shop and an online second-hand book shop, whose father is a banker and mother is a kindergarten teacher, articulates:

Nowadays we have to have some global skill, maybe, and we need some global information. If I know some foreign language I can use it anywhere and it's good to me and I can learn more things.

Because of strong the reliance of the Korean economy on trade, the factors of success in the labor market depend on their openness to complex non-local norms and ideas as well as how well individuals understand global trends and communicate in foreign languages. With a developing proficiency in English, there is a concomitant interest in American cultural and media products, which are widely available, as Yu-chien (21), a male student of astronomy at a local university, whose father is a physician and mother is a housewife in Seoul, reflects:

Every Korean is affected by Western culture, particularly American - you can see it on people on the street.

Youth in Seoul enhance their cosmopolitan capital by travelling and studying abroad, learning English and other foreign languages (Chinese, Japanese and Spanish), as well as consuming foreign cultural products. Many of our interviewees learned English and at least one of the above-mentioned languages, as $\mathrm{Yu}$-chien continues:

Cause nowadays we have to have some global skill, maybe, and we need some global information. If I know some foreign language I can use it anywhere and it's good to me and I can learn more things.

This practical application of the cosmopolitan skill suggests an openness and engagement with the 'other,' but, unlike interviewees from Paris and São Paulo, the purpose of this engagement is not necessarily to gain an in-depth understanding of the 'other' but rather pragmatic: there is a clear costbenefit approach in cosmopolitan cultural consumption. Sun-ok (22), a female student of 
communication and journalism at a local university, whose mother is a teacher, shares her thoughts on this point:

I have thought about living in South America...I think maybe for 3 or 4 years...Because if I work there for 3 or 4 years, I can get enough work experience. So, if I come back to Korea I also can get a job more easily.

And also, Chong-pil (24), a male student studying public administration, whose father is a team leader in chemical industry and mother is a housewife, elaborates:

...I would like to live in Northern Europe if there is a chance...Learning about other cultures is fun, and it helps in the job, because the whole country and the whole company should trade with other countries, so the company needs the citizen of the world...

Traveling overseas does not necessarily lead to an interest in other cultures. Some interviewees travel for work or vacation because this is part of the lifestyle of their social group, but they do not engage in cosmopolitanism in any of the cultural domains. So-young (21), a female student of economics, whose father is a professor and mother is a teacher, explains that it will benefit her own career to be interested in different cultures:

...It depends on whom I am talking to, the country where the person is from. When the person comes from America, I try to speak English because I want to make my English skills more fluently. I only speak Korean with my Korean friends...Ya. I wish to live in America because the second language I can do the best is English so I want to learn more about English...Ya. I am really curious about a lot. I really want to learn more...because it can definitely benefit me. As I said earlier, I want to have a job involving internationally helping businesses with other countries' people, leading them. Therefore, before business, I have to know their culture, people how they are doing in their states, so I think being curious about these cultures can benefit me.

Sun-ok, earlier quoted, also refers to this point:

If you have in your resume that you studied abroad in a foreign country, doesn't matter a lot which country you will get more chances of getting a job. Of getting a good job so that can be like a benefit for me and of course also like understanding of other cultures and being more tolerant and like that.

In addition, while for some interviewees going away to study is very important, coming back to care for parents is essential and a typical stage in the life cycle. Respect for parents and the elderly is 


\subsection{Comparing three uses of aesthetico-cultural cosmopolitanism}

A summary of the comparison between the three uses of aesthetico-cultural cosmopolitanism is presented in Appendix Matrix 3. Among young Parisians, the use of aesthetico-cultural cosmopolitanism is not strategic but rather humanistic, leading to an ethical interest in the 'other' and in certain cases to a willingness to be a "citizen of the world." This self-improvement through globalized cultural consumption parallels the concept of art without instrumental purpose, as Kant (1892) puts it in his analysis of aesthetic judgment. This approach has a long history in Europe and still affects the way youth approach cultural industries. Indeed, most respondents preferred to use aesthetic criteria to justify their taste for foreign TV series, movies, or music, demonstrating a French cultural appropriation that rests on a universalistic vision of the arts. In this context, learning about cultural difference is seen as a vehicle to finding one's place in the world and reaching self fulfilment.

In São Paulo, aesthetico-cultural cosmopolitanism is a reality mostly for the upper classes as a way of enhancing social capital. It is not only a means of connecting to the world and to others but also a way of reproducing distinction in the local society. Due to the strong influence of social inequalities, cultural goods are used mostly as social capital by homogeneous groups comprised of elites and highmiddle class individuals without necessarily leading to a cosmopolitan disposition. Individuals from these groups that have contact with other cultures are those that have a strong cultural influence either from their family (who engage in cosmopolitan cultural consumption) or from their educational background. Mainstream international cultural products are visible and accessible in Brazil. However, it is mainly elite groups that can afford the relatively high-priced international products. Youth in São 
Paulo have contact with different cultures, but their way of developing their cultural capital is less based on global cultural consumption and more reliant on educational and professional support, which is unequally distributed within the society. In contrast to Korea or even France, few individuals go to universities and unemployment is high.

In stark contrast to Paris, appropriation of cosmopolitan skills in Seoul is highly motivated by instrumental benefits. This is not surprising given that global cultural consumption is greatly valued both by the educational system and in the labor market. As most youth pursue higher education as a way into the labor market, the strategic use of cosmopolitan skills is a critical and distinctive factor in enhancing their CVs and getting a good job. Korean society has heavily invested in education to achieve a competitive place in global markets; hence, global resources are expected to be transformed into human capital and are only marginally motivated by cultural development or aesthetic evaluation. The interviewees in Seoul showed a relatively superficial engagement with the aesthetics of global consumption, characterized by little real immersion. While interviewees coming from families with higher economic status could afford to travel, engage in aesthetico-cultural cosmopolitanism, and have contact with foreigners, this did not lead to cultural immersion. Related to this aesthetic distance is the centrality of Confucianism, conservative values, and strong family ties, which shape the way young Koreans manage the tension between family expectations and global cultural consumption leading to the conflict between being culturally open and maintaining traditional conservative values and lifestyles. This results in curtailing the deeper engagement with cosmopolitanism by, for example, spending time overseas but returning to Korea, flirting with Western food but preferring Korean cuisine, and favoring a Korean identity to that of a citizen of the world. Engaging in global cultural consumption is strategic and always negotiated in relation to the payoff in the labor market.

\section{Discussion and Conclusions}

How can aesthetico-cultural cosmopolitanism be transformed into a capital? To answer this question, we rely on Jean-Louis Fabiani's (2016) criteria for establishing what a capital is according to his reading of Bourdieu, and apply it to cosmopolitan cultural capital. Three elements indicate the existence of a capital: the specific realms or different types of competing capitals; the convertibility of a cosmopolitan capital into another type of capital; and the institutions that legitimize that capital, thereby ensuring domination. Because of their characterization as global cities, the three research sites offer similar opportunities for competing types of cultural capitals to develop. However, they differ in 
the degree to which aesthetico-cultural cosmopolitan capital is converted into other types of capital and in the presence of social institutions legitimizing this conversion.

In Paris, aesthetico-cultural cosmopolitanism appears as a new generational good taste, widely disseminated and working as a generational inclusive tool. However, there is no institutional support to convert this aesthetico-cultural cosmopolitanism into cultural capital. The French school system which in the pre-digital era was the institution that converted cultural skills into cultural capital resulting in a high position in the job market, thus conferring cultural legitimacy and economic advantages (Bourdieu and Passeron, 1990) - rarely operates this conversion in the global age of cultural industries. There is a strong reluctance to teach in a foreign language and public resistance to English imperialism stemming from media consumption patterns. The exclusion of media cultures from school curricula is equally telling (Barrère, 2011). Global cultural consumption is seen as an expression of free choice with almost no other perspective than personal pleasure, fulfillment and self-development. Nothing can guarantee that the competences acquired in terms of aesthetico-cultural cosmopolitanism will figure among the soft skills desired by the labor market (Mauléon et al., 2014). This leads to a reproduction of family orientation toward cosmopolitanism. Hence, even if aesthetico-cultural cosmopolitanism is not a capital in France, it is socially stratified and more often found among the more educated and mobile youth (Coulangeon, 2017). Nevertheless, individual aspirations may in certain situations transform power relations among youth and suspend class assignment, as shown in the case of Camille.

In São Paulo, cosmopolitan skills and dispositions resulting from global cultural consumption often accrue only to the well-off, as also found in Hedegard's study (2015), and thus act as a renewed version of distinction, a form of class-based practice, in the construction of social capital. For those who are poor and live the difficulties of social inequalities in the city, there are many barriers to understand different cultural codes and to explore with voracity different opportunities worldwide. Still, these young individuals try to localize cultural contents, inserting elements from global products in their own cultural expressions. In these experiences, aesthetic codes are hybridized from international references to national cultural products - as Garcia Canclini (1998) also points out in his analysis about Latin America - showing alternatives to the consumption of global products but not necessarily enhancing the individuals' social capital.

Aesthetico-cultural cosmopolitan is transformed into a capital in Korea primarily in the labor market. One reason for this limited embrace of aesthetico-cultural cosmopolitanism is conservativism 
due to Koreans' Confucian roots, deeply rooted in status consciousness in terms of lineage, property and education. Korean society is not uniformly conservative across generations and for the youth, cosmopolitanism often counteracts the effects of Confucianism; the emphasis on tradition is waning and there is a growing centrality of education, which leads to openness and better life prospects. Acquiring cosmopolitan skills and dispositions acts as a signal of legitimacy in the labor market and since such an undertaking is not without cost in time, effort and money, Korean youth are decidedly instrumental and strategic in the way they acquire these skills, especially foreign language skills and travel experiences. The emphasis on cosmopolitan competence encourages youth from all socioeconomic backgrounds to acquire this capital in a very hierarchical society. For example, those students denied entrance to the elite colleges find that their labor market opportunities are limited, and in the face of unprecedented high rates of continued youth unemployment and insecurity, one of the means to acquire legitimacy and improve their life chances is accessing cosmopolitan capital through English study abroad experiences (Anagnost et al., 2013). This enhances their linguistic and cultural capital, legitimizes them in the eyes of their peers and increases their chances of success in the job market. Thus, in Seoul, there is strong institutional support and expectation for demonstrating familiarity with cosmopolitan cultural codes and foreign languages. Young individuals make educational and personal choices based on this expectation early on in their educational and occupational careers and the costs of engaging with cosmopolitan cultural consumption are negotiated and often result in a superficial level of cultural engagement. The conversion of cultural capital into human capital occurs on multiple axes, relying on competence that draws from Western and Eastern cultures.

Future research on the comparison presented here is needed to further develop how mechanisms of distinction rely on new forms of cultural capital generated in different regions of the world. This can be pursued along two lines of inquiry. First, the routes through which and the degree to which social institutions can adapt to have a better fit with emerging types of cultural capital. Second, the effect of processes of new capital creation on existing cultural and economic hierarchies and inequalities. These emphases for future research stem from our finding that even with the prevalence of cultural globalization in global cities, the functions of cosmopolitan skills remain highly dependent on educational, institutional, cultural and political contexts at the national level, which create different opportunities or barriers to experiencing otherness and developing new types of cultural capital. 


\section{REFERENCES}

Ablas L (1993) São Paulo: cidade mundial ou metrópole subdesenvolvida? São Paulo em Perspectiva, Revista da Fundação SEADE 7(2): 45-49.

Anagnost A, Arai A and Ren H (eds) (2013) Global futures in East Asia: Youth, nation, and the new economy in uncertain times. Stanford: Stanford University Press.

Appadurai A (1996) Modernity at large. Cultural dimensions of globalization. Minneapolis: University of Minnesota Press.

Barrère A (2011) L'Education buissonnière. Paris: Armand Colin.

Beck U (2006) Cosmopolitan Vision. Cambridge: Polity Press.

Beck U and Grande E (2010) Varieties of Second Modernity: The Cosmopolitan Turn in Social and Political Theory and Research. The British Journal of Sociology 61(3): 409-443.

Bourdieu P (1984) Distinction: A Social Critique of the Judgement of Taste. London: Routledge.

Bourdieu P and Passeron JC (1990 (1970)) Reproduction in Education, Society and Culture. London: Sage.

Caldeira T (2000) Cidade de Muros: Crime, Segregação e Cidadania em São Paulo. São Paulo: Editora 34/Edusp.

Calver C and Pichard L (2015) L'Ile-de-France, capitale des étudiants et des diplômés du supérieur. Insee Analyse Ile de France 19. https://www.insee.fr/fr/statistiques/1288219 (accessed 20 September 2018)

Canclini NG (1998) Culturas hibridas: estratégias para entrar e sair da modernidade. São Paulo: Edusp. 
Cappeliez S and Johnston J (2013) From Meat and Potatoes to 'Real-Deal' Rotis: Exploring Everyday Culinary Cosmopolitanism. Poetics 41(5): 433-455.

\begin{abstract}
Cetic - Comitê Gestor da Internet no Brasil (2017) Pesquisa sobre o uso das tecnologias de informação e comunicação nos domicílios brasileiros: TIC domicílios 2016, Núcleo de Informação e Coordenação do Ponto BR. https://cetic.br/publicacao/pesquisa-sobre-o-uso-das-tecnologias-de-informacao-e$\underline{\text { comunicacao-nos-domicilios-brasileiros-tic-domicilios-2016 }}$
\end{abstract}

Cicchelli V and Octobre S (2017) Aesthetico-Cultural Cosmopolitanism among French Young People: Beyond Social Stratification. The Role of Aspirations and Competences. Cultural Sociology 11(4): 416-437.

Cicchelli V and Octobre S (2018) Aesthetico-Cultural Cosmopolitanism and French Youth - The Taste of the World. London: Palgrave.

Coulangeon P (2017) Cultural Openness as an Emerging Form of Cultural Capital in Contemporary France. Cultural Sociology 11(2): 145-164.

Dauncey H (2010) L'exception culturelle. In: Chafer T and Godin E (eds) The End of the French Exception? Decline and Revival of the 'French Model.' London: Palgrave Macmillan, pp. 72-84.

Dharwadker V (2011) Diaspora and Cosmopolitanism. In: Rovisco M and Nowicka M (eds) The Ashgate Research Companion to Cosmopolitanism. Farhnam: Ashgate, pp.125-144.

EF English proficiency Index (2018) Available at: https://www.ef.fr/epi/

Fabiani JL (2016) Pierre Bourdieu. Un structuralisme hérö̈que. Paris: Seuil.

Faucon F (2018) Le taux de chômage en Ile-de-France au cours des vingt dernières années. Insee Flash Ile-de-France 31. https://www.insee.fr/fr/statistiques/3313799 (accessed 20 September 2018) 
Germann Molz JG (2011) Cosmopolitanism and Consumption. In: Rovisco M and Nowicka M (eds) The Ashgate Research Companion to Cosmopolitanism. Farnham: Ashgate, pp.33-52.

Gombault V (2013) L'internet de plus en plus prisé, l'internaute de plus en plus mobile. Insee Première 1452.

Grauel J (2016) Being authentic or being responsible? Food consumption, morality and the presentation of self. Journal of Consumer Culture 16(3): 852-869.

Hannerz U (1990) Cosmopolitans and Locals in World Culture. Theory, Culture and Society 7(2-3): 237-251.

Hedegard D (2015) Transnational Connections: The Meaning of Global Culture in the Tastes of Brazilian Elites. Poetics 53: 52-64.

Héran F (2013) L'anglais Hors La Loi? Enquête sur les langues de recherche et d'enseignement en France. Population et Sociétés 501: 1-12.

IBGE (2010) Censo 2010, IBGE (database), https://censo2010.ibge.gov.br (accessed 15 June 2018).

IBGE (2014) População economicamente ativa (PEA), IBGE Estatística Indicadores, (database), https://ww2.ibge.gov.br/home/estatistica/indicadores/trabalhoerendimento/pme_nova/default tab hist.shtm (accessed 15 June 2018).

Igarashi H and Saito H (2014) Cosmopolitanism as Cultural Capital: Exploring the Intersection of Globalization, Education and Stratification. Cultural Sociology 24: 1-18.

INEP (2017) Resultados finais do Censo Escolar, INEP Censo Escolar, (database), http://inep.gov.br/resultados-e-resumos (accessed 15 June 2018). 
Internet World Stats (2018) https://www.internetworldstats.com/ (accessed 20 October, 2018)

Jin D (2016) New Korean Wave: Transnational cultural power in the age of social media. Champaign: University of Illinois Press.

Johnston J and Baumann S (2014) Foodies: Democracy and distinction in the gourmet foodscape. London: Routledge.

Kant E (1892) Critique of Judgement. New York: Hafner Publishing.

Katz-Gerro T (2017) Cross-National Differences in the Consumption of Non-National Culture in Europe. Cultural Sociology 11(4): 438-467.

Kendall G, Woodward I and Skrbis Z (2009) The Sociology of Cosmopolitanism: Globalization, Identity, Culture and Government. New York: Palgrave Macmillan.

Koo H (2007) The Changing Faces of Inequality in South Korea in the Age of Globalization. Korean Studies 31(1): 1-18.

Lamont M and Aksartova S (2002) Ordinary Cosmopolitanisms: Strategies for Bridging Racial Boundaries among Working-Class Men. Theory, Culture and Society 19(1): 1-25.

Lizardo O (2006) How Cultural Tastes Shape Personal Networks. American Sociological Review 71(5): 778-807.

Lombard A (2003) Politique culturelle internationale : le modèle français face à la mondialisation. Arles: Actes Sud.

Mau S, Mewes J and Zimmermann A (2008) Cosmopolitan Attitudes through Transnational Social Practices? Global Networks 8(1): 1-24. 
Mauléon F, Bouret J and Hoarau J (2014). Le réflexe soft skills. Les compétences des leaders de demain. Paris: Dunod.

Maurin E (2009) La Peur du Déclassement: Une Sociologie des Récessions. Paris: Seuil.

Meuleman R and Savage M (2013) A Field Analysis of Cosmopolitan Taste: Lessons from the Netherlands. Cultural Sociology 7(2): 230-256.

Moon KH (2015) South Korea's Demographic Changes and their Political Impact. The Brookings Institution: Center for East Asia Policy Studies 6(10): 1-24

OECD (2018), Education at a glance: Educational attainment and labour-force status, $O E C D$ Education Statistics (database), https://doi.org/10.1787/889e8641-en (accessed 6 May 2018).

Papastergiadis N (2012) Cosmopolitanism and Culture. Cambridge: Polity.

Park JSY (2011) The promise of English: Linguistic capital and the neoliberal worker in the South Korean job market. International Journal of Bilingual Education \& Bilingualism, 14(4): 443-455.

Park YS (2014) Trade in cultural goods: A case of the Korean wave in Asia. Journal of East Asian Economic Integration, March 18(1): 83-107

Pieterse JN (2006) Emancipatory Cosmopolitanism: Towards an Agenda. Development and Change 37(6): 1247-1257.

Poulet-Coulibando P and Testas A (2017) Le niveau d'études de la population et des jeunes. Ministère de l'Enseignement supérieur et de la Recherche.

https://publication.enseignementsup-recherche.gouv.fr/eesr/10/EESR10 ES 20-

le niveau d etudes de la population et des jeunes.php (accessed 20 September 2018)

Regev M (2013) Pop-Rock Music: Aesthetic Cosmopolitanism in Late Modernity. Cambridge: Polity. 
Robertson R (1992) Globality and Modernity. Theory, Culture and Society 9(2):153-161.

Rolnik R, Kowarick L and Somekh N (1990) São Paulo: crise e mudança. São Paulo: Brasiliense.

Rössel J and Schroedter J (2015) Cosmopolitan Cultural Consumption: Preferences and Practices in an Heterogenous Urban Population in Switzerland. Poetics 50: 80-95.

Sassen S (2001) The Global City: New York, London, Tokyo. Princeton: Princeton University Press.

Savage M, Hanquinet L, Cunningham N and Hjellbrekke J (2018) Emerging Cultural Capital in the City: Profiling London and Brussels. International Journal of Urban and Regional Research 42(1): $138-149$.

Seabrook J (2012, October 8). Factory girls. The New Yorker. Available at: http://www.newyorker.com/magazine/2012/10/08/factory-girls-2 (accessed April 25, 2018)

Seo Y and Gao H (2015) Towards a value-based perspective of consumer multicultural orientation. European Management Journal 33(1): 30-36.

Skrbis Z and Woodward I (2013) Cosmopolitanism: Uses of the Idea. London: Sage.

e-Seoul Statistics (2018) Statistical Analysis http://stat.seoul.go.kr/ (accessed October 20, 2018)

Sullivan A (2001) Cultural Capital and Educational Attainment. Sociology 35(4): 893-912.

Szerszynski B and Urry J (2002) Cultures of Cosmopolitanism. The Sociological Review 50(4): 461481.

Szerszynski B and Urry J (2006) Visuality, Mobility, and the Cosmopolitan. Inhabiting the World from Afar. British Journal of Sociology 57(1): 133-151. 
Tomlinson J (1999) Globalization and Culture. Chicago: University of Chicago Press.

Tribalat M (2013) Assimilation: La Fin du Modèle Français. Paris: Le Toucan.

Unesco Institute for Statistics (2016) The globalization of cultural trade: a shift in consumption. http://uis.unesco.org/sites/default/files/documents/the-globalisation-of-cultural-trade-a-shift-inconsumption-international-flows-of-cultural-goods-services-2004-2013-en_0.pdf $\quad$ (accessed 20 September 2018)

Warde A and Tampubolon G (2002) Social Capital, Networks and Leisure Consumption. The Sociological Review 50(2): 155-180.

Weenink D (2008) Cosmopolitanism as a Form of Capital: Parents Preparing their Children for a Globalizing World. Sociology 42(6): 1089-1106.

Yeoh SAB (2005) The global cultural city? Spatial Imagineering and politics in the (multi)cultural marketplaces of South-East Asia. Urban Studies 42(5-6): 945-958 


\section{Appendix}

\section{Matrix 1: The place of the three cities in the global arena of culture}

\begin{tabular}{|c|c|c|c|}
\hline & $\begin{array}{l}\text { Paris } \\
\text { City Population: } \\
10 \text { million } \\
\end{array}$ & $\begin{array}{l}\text { São Paulo } \\
\text { City Population: } \\
11 \text { million }\end{array}$ & $\begin{array}{l}\text { Seoul } \\
\text { City Population: } \\
10.4 \text { million }\end{array}$ \\
\hline $\begin{array}{l}\text { Place in the } \\
\text { cultural } \\
\text { flow }\end{array}$ & $\begin{array}{l}\text { Central and worldwide sphere of } \\
\text { influence } \\
\text {-Universalism of the Parisian culture and } \\
\text { tradition of openness } \\
\text {-"Exception culturelle" + a long-standing } \\
\text { anti-American stance juxtaposes the } \\
\text { French highbrow cultural soft power and } \\
\text { the American lowbrow culture } \\
\text { (Dauncey, 2010; Maurin, 2009) } \\
\text { An old global player } \\
\text { Important exports (over 9000 million US } \\
\text { dollars) and imports (more than } 8700 \\
\text { million US dollars) of cultural goods: } \\
\text { France has a balanced trade coverage ratio } \\
\text { of cultural good (103.5\%) } \\
\text { (Unesco, 2016) }\end{array}$ & $\begin{array}{l}\text { Peripheral, searching for a regional } \\
\text { centrality } \\
\text { - Soft power and challenges of social } \\
\text { inequalities } \\
\text { - Regional influence and cultural barriers } \\
\text { (Caldeira, 2000; Rolnik et al., 1990) } \\
\text { Trying to play global } \\
\text { Exports are low (289 million of US dollars) } \\
\text { and imports much higher (almost } 800 \text { million } \\
\text { of US dollars): a very unbalanced trade } \\
\text { coverage ratio ( } 37 \% \text { ) } \\
\text { (Unesco, 2016) }\end{array}$ & $\begin{array}{l}\text { Gaining soft power } \\
\text {-Japanese and Chinese } \\
\text { influence of colonization } \\
\text {-US influence since WW } \\
\text { II } \\
\text { A new global player: } \\
\text { Korean export of cultural } \\
\text { contents: 2009-2011 } \\
\text { Grown from \$2435 } \\
\text { million to \$4146 million } \\
\text { (KOCCA as cited in Park, } \\
\text { 2014) } \\
\text { Music gaining global } \\
\text { influence since 1990’s in } \\
\text { Asia, Latin America, } \\
\text { Africa and North America } \\
\text { (Seabrook, 2012) }\end{array}$ \\
\hline $\begin{array}{l}\text { Diversity } \\
\text { of } \\
\text { population }\end{array}$ & $\begin{array}{l}\text { Mixed origins: High proportion of mixed } \\
\text { origins }(52 \%)+\text { regular migration }(7 \%) \\
\text { (Tribalat, 2013) }\end{array}$ & $\begin{array}{l}\text { Mixed origins: Low proportion of foreign } \\
\text { born }(1.8 \%) \text { but high proportion of mixed } \\
\text { race }(43 \%)+\text { migration }(2.3 \%) \text { (IBGE, } 2010)\end{array}$ & $\begin{array}{l}\text { Homogenous: Low } \\
\text { proportion of foreign born } \\
\text { or foreign origin }(4 \%) \\
\text { e-Seoul Statistics }(2018)\end{array}$ \\
\hline
\end{tabular}


Matrix 2: Youth in three cities

\begin{tabular}{|c|c|c|c|}
\hline & Paris & São Paulo & Seoul \\
\hline Demographic & $\begin{array}{l}\text { Proportion of Youth: 17\% } \\
\text { (Calver and Pichard, 2015) }\end{array}$ & Proportion of youth : $9 \%$ (IBGE, 2010) & $\begin{array}{l}\text { Proportion of youth in total population } \\
13 \%(15-24 \text { years })\end{array}$ \\
\hline $\begin{array}{l}\text { Social position } \\
\text { and occupation }\end{array}$ & $\begin{array}{l}\text { Students: } 47 \% \text { of } 18-24 \text { y.o. are students } \\
\text { (Calver and Pichard, 2015) } \\
18 \% \text { unemployment rate for youth aged } 15- \\
24 \text { (versus } 8.7 \% \text { for all) } \\
\text { and } 24,9 \% \text { in the rest of the country (Faucon, } \\
2018 \text { ) }\end{array}$ & $\begin{array}{l}\text { Students: } 4.3 \% \\
\text { of the youth are in university (INEP, } \\
\text { 2017) } \\
\text { high level of unemployment: } 24.1 \% \\
\text { (IBGE, 2014) }\end{array}$ & $\begin{array}{l}\text { Students } \mathbf{1 0 \%} \text { of the total population } \\
-86 \% \text { of all high school graduates go on } \\
\text { to college, about } 3.3 \text { million students are } \\
\text { enrolled in } 347 \text { universities - one of } \\
\text { every } 14 \text { South Koreans is a university } \\
\text { student } \\
\text { e-Seoul Statistics (2018) } \\
\text { Unemployment rates } \\
9.9 \text { percent in } 2017 \text { for youth } 15-29 \\
\text { versus } 3.7 \text { for all } \\
\text { e-Seoul Statistics (2018) }\end{array}$ \\
\hline Education & $\begin{array}{l}\text { High level of education: more than } 80 \% \\
\text { reach the baccalaureate and } 45 \% \text { university } \\
\text { degrees (Poulet-Coulibandot and Testas, } \\
\text { 2017) } \\
\text { Educational system remains defensive toward } \\
\text { the introduction of courses in English at the } \\
\text { university level (Héran, 2013) }\end{array}$ & $\begin{array}{l}\text { Low level of education } \\
\text { but the highest in the country: } 4.5 \% \\
\text { (INEP, 2017) }\end{array}$ & $\begin{array}{l}\text { Very high level of education for youth: } \\
99 \% \text { graduate from high school and over } \\
69 \% \text { have post-secondary degrees } \\
\text { OECD (2018) } \\
\text { US based lifestyles and education valued, } \\
\text { level of English proficiency Park (2011) }\end{array}$ \\
\hline $\begin{array}{l}\text { Cultural devices } \\
\text { used by youth }\end{array}$ & $\begin{array}{l}\text { Internet access: } \\
96 \% \text { internet access (mainly through } \\
\text { smartphones) (Gombault, 2013) }\end{array}$ & $\begin{array}{l}\text { Internet access: } \\
67 \% \text { of Internet access, } 96 \% \text { through } \\
\text { smartphones (Cetic, 2017) }\end{array}$ & $\begin{array}{l}\text { Internet access: } \\
99.2 \% \text { households have internet access } \\
92.6 \% \text { of the total population use the } \\
\text { Internet. } \\
96.8 \% \text { of South Korean mobile phones } \\
\text { had Internet access } \\
\text { Internet World Stats (2018) }\end{array}$ \\
\hline
\end{tabular}


Matrix 3: Uses of aesthetico-cultural cosmopolitanism

\begin{tabular}{|c|c|c|c|}
\hline & Paris & São Paulo & Seoul \\
\hline $\begin{array}{l}\text { Global cultural products } \\
\text { consumed }\end{array}$ & $\begin{array}{l}\text { Flows coming mainly } \\
\text { from Western Europe } \\
\text { and the US, and recently } \\
\text { Asia (especially Japan } \\
\text { and Korea) }\end{array}$ & $\begin{array}{l}\text { Flows coming mainly } \\
\text { from the US and } \\
\text { Western Europe }\end{array}$ & $\begin{array}{l}\text { Flows coming mainly } \\
\text { from the US, Japan and } \\
\text { Western Europe in terms } \\
\text { of cultural products }\end{array}$ \\
\hline $\begin{array}{l}\text { Type of aesthetico-cultural } \\
\text { cosmopolitanism }\end{array}$ & $\begin{array}{l}\text { An emphasize on } \\
\text { aesthetics (sounds, } \\
\text { voice) } \\
\text { Non-instrumental } \\
\text { curiosity about culture } \\
\text { (learning to understand) }\end{array}$ & $\begin{array}{l}\text { An emphasis on } \\
\text { distinctive cultural } \\
\text { repertoire } \\
\text { Aesthetic codes are } \\
\text { shared within specific } \\
\text { groups (learning to } \\
\text { reproduce behaviors) }\end{array}$ & $\begin{array}{l}\text { An emphasize on } \\
\text { instrumental learning } \\
\text { about culture (workplace } \\
\text { and social norms and } \\
\text { expectations different } \\
\text { cultures, language } \\
\text { proficiency) }\end{array}$ \\
\hline $\begin{array}{l}\text { Social sphere relevant to aesthetic } \\
\text { cultural cosmopolitanism }\end{array}$ & Media-cultures & Social network & $\begin{array}{l}\text { Educational system } \\
\text { Job market }\end{array}$ \\
\hline $\begin{array}{l}\text { Uses of aesthetico-cultural } \\
\text { cosmopolitan skill }\end{array}$ & $\begin{array}{l}\text { For self-improvement in } \\
\text { a context of an absence } \\
\text { of institutional support }\end{array}$ & $\begin{array}{l}\text { For social capital } \\
\text { towards social } \\
\text { inclusion in a context } \\
\text { where job } \\
\text { opportunities are } \\
\text { scarce }\end{array}$ & $\begin{array}{l}\text { For developing human } \\
\text { capital enabling entrance } \\
\text { into the prestigious strata } \\
\text { of the job market }\end{array}$ \\
\hline
\end{tabular}

